\title{
NEW INSIGHTS INTO KARST AND CAVES OF NORTHWESTERN ZAGROS (NORTHERN IRAQ)
}

\section{NOVI POGLEDI NA KRAS IN JAME V SEVEROZAHODNEM ZAGROSU (SEVERNI IRAK)}

\author{
Zoran STEVANOVIĆ ${ }^{1}$, Adrian IURKIEWICZ ${ }^{2}$ \& Aleksandra MARAN ${ }^{3}$
}

\begin{abstract}
UDC 911.2:551.44(567-179)

Zoran Stevanovic, Adrian Iurkiewicz \& Aleksandra Maran: New insights into karst and caves of northwestern Zagros (northern Iraq)

During 2002, several reconnaissance speleological explorations were undertaken by the authors and local enthusiasts in the karst of Northwestern Zagros in Northern Iraq. Some of the caves were visited for the first time and explored to a great depth by the scientists, while the Shanidar cave is a world-famous site representing one of the oldest discovered and investigated human settlements. The explored caves are located in well-karstified limestones of the Cretaceous age as well as in younger Eocene limestones. This paper contains the data from the nine largest caves. Their total explored lengths range from a few tens of meters up to several hundred meters. Four caves are fossil, containing only percolated water, while five represent still hydrogeologically active features. Two of them have resulted from the dissolution of carbonate or evaporate rocks stimulated by water oversaturated in $\mathrm{H}_{2} \mathrm{~S}$ which migrated from deeper oil-bearing structures.

Keywords: karst, cave, Zagros, northern Iraq.
\end{abstract}

Izvleček:

UDK 911.2:551.44(567-179)

Zoran Stevanovic, Adrian Iurkiewicz \& Aleksandra Maran: Novi pogledi na kras in jame $v$ severozahodnem Zagrosu (severni Irak)

Leta 2002 so avtorji in lokalni navdušenci opravili več poizvedovalnih speleoloških raziskav na krasu severozahodnega dela gorovja Zagros v severnem Iraku. Nekaj jam so raziskovalci sami odkrili in jih raziskali do velikih globin, medtem ko jama Shanidar slovi v svetu kot ena najstarejših odkritih in raziskanih človeških naselbin. Jame, ki so jih raziskali, so tako v dobro zakraselih krednih kot tudi v mlajših eocenskih apnencih. Prispevek podaja podatke o devetih največjih jamah, ki so dolge od nekaj deset pa do več sto metrov. Štiri jame so fosilne, z zgolj kapljajočo vodo, ostalih pet pa je hidrološko aktivnih. Dve jami sta nastali z raztapljanjem karbonatnih ali evaporitnih kamnin potom vode, prenasičene $\mathrm{s}_{2} \mathrm{~S}$, pritekajoče iz globljih naftonosnih struktur.

Ključne besede: kras, jama, Zagros, severni Irak.

\section{INTRODUCTION}

During the period of 2000-2003, the first two authors of this paper led large-scale geologic and geophysical investigations, groundwater monitoring (wells and springs), remote sensing analysis, and groundwater quality assessment in the northern part of Iraq (Iraqi Kurdistan) under the FAO Programme (part of the "Oil for Food" UN activities). The third author worked on foundation of the Natural History Museum at Sulaimani University.

Very limited time, lack of adequate equipment, as well as political and security conditions in the area impeded the extensive surveys necessary to achieve a consistent and more detailed image of cave development in

\footnotetext{
${ }^{1}$ Department of Hydrogeology, University of Belgrade - Faculty of Mining and Geology; FAO Consultant, Serbia, zstev@eunet.rs

${ }^{2}$ Research Department of Environmental Geology and Geophysics, University of Bucharest; FAO Consultant, Romania, aiwicz@yahoo.com

${ }^{3}$ Natural History Museum, Belgrade, Serbia, amaran@nhmbeo.org.rs

Received/Prejeto: 24.04.2008
} 
the region. Nevertheless, the important goal of this paper is to disseminate the acquired knowledge and also to open a gate for further surveys in the interesting Kurdistan karst.

Therefore, such a Kurdish - German cave surveying project has been recently conducted. It was carried out on invitation of the Kurdish Minister of Tourism and with logistical support by the Museum of Antiquities in Sulaimani. Within 3 weeks 21 caves with a total passage length of 8,115 metres were mapped, firmly establishing Kuna Kamtiar as the longest cave of Iraq currently 5,060 $\mathrm{m}$ in length (Laummans et al. 2008).

\section{LANDSCAPE AND LIVING IN CAVES}

Northern Iraq is a land that comprises parts of Lower $\mathrm{Za}$ gros and Upper Mesopotamia (Fig. 1).

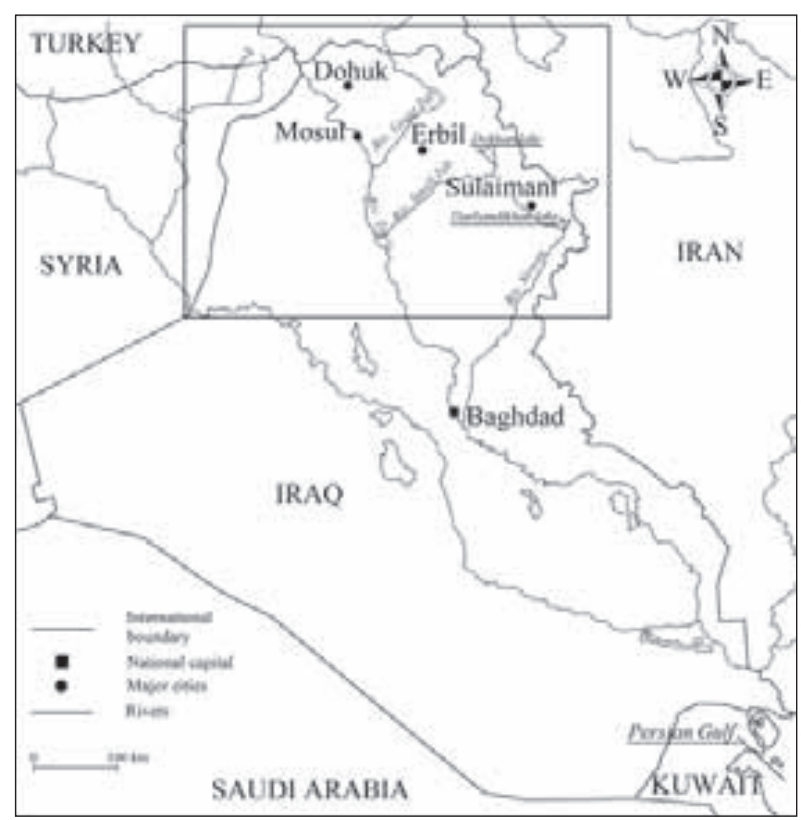

Fig. 1: Geographic position of Northern Iraq

The Zagros Mts. chain represents the southern, Asian branch of the Alpine geosyncline. The name Zagros is derived from the Zagarthians/Sagarthians, and Indo-European, Iranic immigrants from Europe who once inhabited these mountains. The total length of the chain is over 2,500 $\mathrm{km}$ from the Iraqi Kurdistan region to the southern parts of the Persian Gulf in Iran. The highest points in the Zagros range are over 4,000 m above sea level (a.s.l.). On the Iraqi side, highly folded massive limestone cliffs dominate rich fertile valleys and villages crouching beneath the tall mountains. The rainfall is much higher than in the rest of Iraq and often well over $1,000 \mathrm{~mm}$ per year, including a considerable amount of snow during the winter.

The Zagros Mts. foothill extends to Upper Mesopotamia which represents a vast rolling plain bounded mainly by the sharp valleys of the Tigris and Euphrates rivers. Its altitude varies from 150 to $400 \mathrm{~m}$ a.s.l. with a number of small closed basins from which there are often no drainage outlets. The remote history of Upper Mesopotamia, particularly of the Sumerian and Assyrian periods, provides a uniquely rich and significant contribution to the study of the human past, and the area is often called "the cradle of civilization". Earlier hominids obviously lived in northern Mesopotamia for millennia, but they left modest material evidence to testify to the nature of their dwelling. Direct evidence of Lower Paleolithic occupation in Mesopotamia proper is limited. But during the Middle and Upper Paleolithic periods, life in caves and shelters as main settlements prevailed.

In the late 1920s, American and British researchers initiated the first archaeological investigations in the region. The earliest forms of hominid, probably Homo erectus and certainly Neanderthals (Shanidar Cave) with discovered tools and artifacts from many locations across north Iraq (Zawi Chami, Zarzi Cave, Hazar Merd Cave), add a new geographic perception to the study of the $\mathrm{Pa}$ leolithic, Mesolithic and Neolithic periods (Solecki Ro. 1981, Solecki Ra. 1988). Braidwood and Howe (1960) started to explore the field evidence for the transition from the hunter-gatherer way of life to sedentary food production in the region surrounding the Mesopotamian Plain. By excavating the Shanidar cave, Solecki Ra. (1952) and his team of archaeologists discovered artifacts and skeletal remains that offer impressive evidence of prehistoric culture and specifically of the origins of agriculture and trade. Thirty-five bodies in twenty-six burials and the associated artifacts were recovered from the upper level of the cave. Associated with the burials was a special assemblage of funerary goods and human remains that provide new traces to the familial relationships and lifestyles of these earlier humans.

Man-made caves are also an ancient art found in many places. Some of them, the Bavian (Khanis) in the vicinity of Atrush (Fig. 2) were constructed above the first intake structure and aqueduct that conveyed water by gravity to the ancient site of Nineveh (during the 


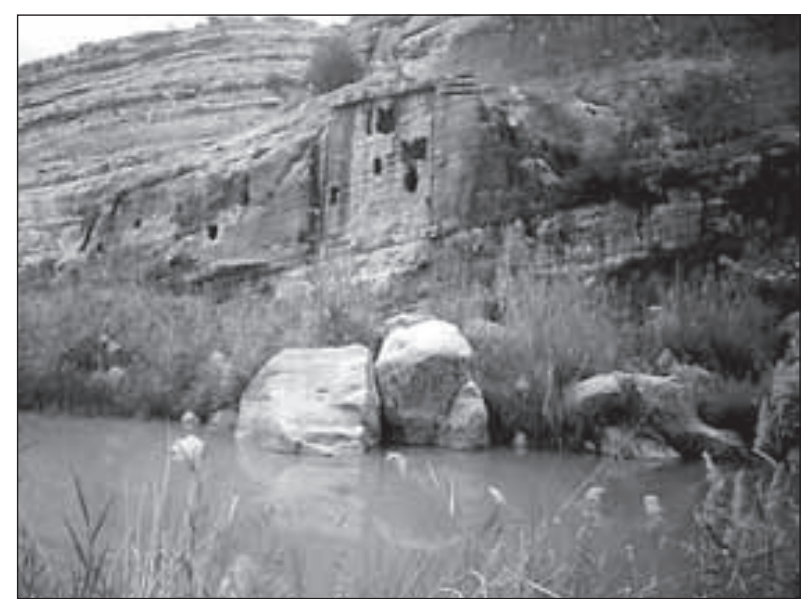

Fig. 2: Man-made cave: Bavian (Khanis). (Photo: Z Stevanović).
Assyrian king Sanherib, son of Sargon II). Similar manmade caves have also been found in Deralok valley (the right Great Zab tributary). These caves are generally of small dimensions compared to natural caverns and may contain artifacts that support the evidence of a long human inhabitation (Maran et al. 2004).

Many of the caves are used as human and animal settlements during hot summers, or even exploited as a restaurant in some tourist areas (Anishke waterfall, Dohuk Gov.). Some others such as Sahra cave (Laummans et al. 2008) have recently provided safe haven for Kurdish rebels against the central Iraqi Government (peshmarga resistance)

\section{GEOLOGY AND HYDROGEOLOGY}

Systematic geological investigations in Iraq started in the early 1920s and were aimed at the assessment of oil resources. One of the most important works describing the regional geology of Iraq was published in 1959 as a volume of Lexique Stratigraphique International (book 10a, Asie-Iraq), edited by Dubertret. The main geological data and information were collected in the sixties and seventies (published by Buday et al. 1980; Buday \& Jassim, 1987); however, up to this point, little attention has been paid to karst phenomena and groundwater resources, so karst aquifer investigation and exploitation is still at an early stage.

The extensive hydrogeological research within the frame of the UN / FAO Programme provided essential data for the analysis of groundwater flow patterns, spring occurrence and discharge regime. The results of the research assisted in the selection of priority areas for drilling (some 500 new deep wells were drilled) or proposals for proper water management and control of the discharge zone, which are essential to mitigate the consequences of the severe drought that sometimes occurs in this region (Stevanovic \& Iurkiewicz 2004a).

In the northern part of Iraq (Dohuk, Erbil and Sulaimani governorates) three major tectonic zones occur: Thrust Zone (1), High Folded Zone (2), and Low Folded Zone (3). Similarly, from N to S, three major morphologic units developed: mountainous ranges, foothill pediments and agricultural plains (Numan 2002), followed by typical landforms: anticline ridges, structural denudation hills and slopes, and fluvial accumulation plains (Fig. 3).

The thrust or nappe zone occupies strips of Iraqi Kurdistan territory near borders with Turkey and Iran.
It is a zone of intensive mobility and differentiation that contains geological formations from pre-Triassic and Jurassic to late Tertiary times. In the High Folded Zone Balambo, Sarmord and Qamchuga Formations date from the late Lower Cretaceous phase (Aptian and Albian ages) and they are often massive and dominantly carbonate (limestones and dolomitized limestones).

The lower and the middle part of the Upper Cretaceous rocks also consist of carbonates (Kometan, Dokan, Bekhme, Aqre Fns.) as well as "impure" carbonate (Shiranish) and clastic rocks (Tanjero). The total thickness of each varies between 100 and $500 \mathrm{~m}$. A great inclination of layers resulted from intensive orogenic movements (Stevanovic \& Markovic 2004).

During the Paleogene era, different deposition environments (neritic and bathyal) and lateral variation influenced the creation of alternately carbonate (Sinjar, Khurmala, Pila Spi Formations) and flysch sediments (Gercus). After the Oligocene and Lower Miocene regression phases, the sedimentation cycle continued during the Middle and Upper Miocene periods when thick layers of Lower and Upper Fars sediments were deposited (Fig. 3). Their facies are very heterogeneous, comprising marls, sandstones, anhydrite, gypsum, conglomerates, clays and sand. The youngest Neogene Lower and Upper Bakhtiari sediments are over a thousand meters thick and composed of almost entirely terrigenous clastics from silt-size to boulder conglomerates eroded and transported from the Zagros Mts.

The Tectonic characteristic of the High and Low Folded Zones is the occurrence of long linear double plunging folds, with anticline structures such as mountain 


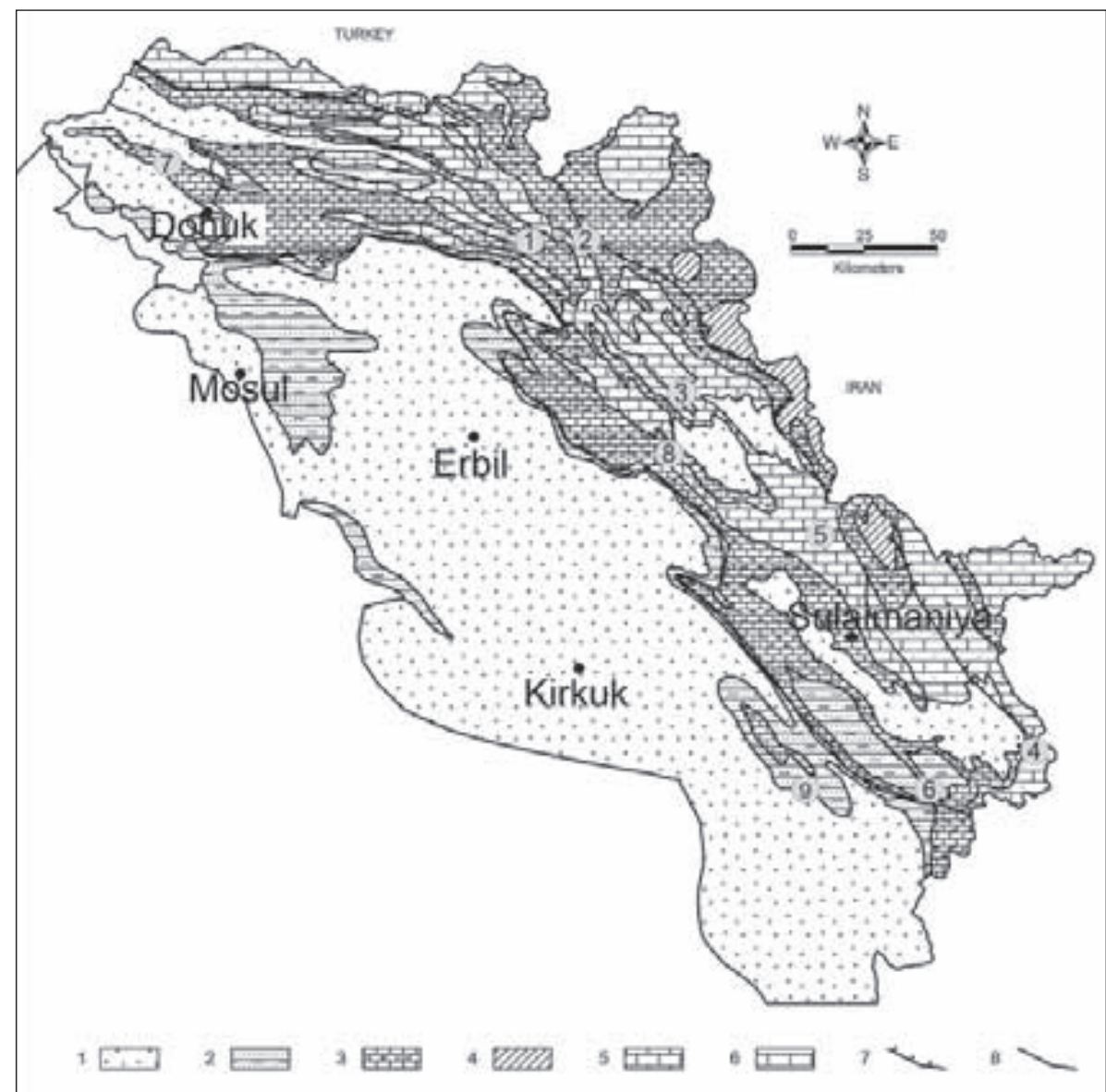

Fig. 3: Karst and karst-fissured aquifers in Northern Iraq and locations of explored caves (no. 1-9).

1 - Recent alluvial deposits, Lower and Upper Bakhtiari Fns. conglomerates, gravel, sand, clay; 2 - Lower and Upper Fars Fns. evaporites; Red beds series; 3 - Pila Spi, Gercus, Sinjar, Kolosh, Tanjero and Shiranish Fns. - Tertiary karstic - fissured aquifers and aquicludes; 4 -Ophiolite and Qandil series; 5 - Aqra, Bekhme, Qamchuga, Kometan, Dokan Fns. - Cretaceous karstic aquifers and aquicludes; 6 - Qulqula Group, Balambo, Chia Gara, Naokelekan, Avroman, Piriskipi, Khabour and other older Fns.; 7 - Thrust; 8 - Lithostratigraphic boundaries.

ridges and intermountain valleys in synclines between them. Intensive uplifting and folding of the sedimentary complex sequence are the result of Alpine orogenic polyphase deformation. Numerous regional faults, following the longitudinal tectonic trend, or sometimes transversal to the main structures, control both river valley orienta- tion and preferred groundwater pathways (Stevanovic \& Iurkiewicz 2004c).

The two main aquifer systems in carbonate rocks are considered of great significance for groundwater use (Stevanovic \& Iurkiewicz 2004a).

Karst aquifer "Bekhme" comprises Cretaceous / $\mathrm{Pa}$ leocene age formations, developed mainly in carbonate facies (limestones and dolomites and their varieties). This aquifer system is widespread in the northern and central parts of Northern Iraq and contains large groundwater reserves, albeit varying in space and time. The aquifer is highly fissured and wellkarstified with many channels and caves that were registered on the surface or during the drilling of many wells.

Fissured-karstic "Pila Spi" aquifer in the centralsouthern part consists of Eocene limestones, sometimes up to $200 \mathrm{~m}$ thick. The aquifer is characterized by a continuous surface extension in a NW-SE direction in the central and southern part of Northern Iraq and contains medium to large groundwater reserves, also varying in space and time. The average widths of the Pila Spi hilly range vary from $1-2 \mathrm{~km}$ to more than ten $\mathrm{km}$. The Pila Spi aquifer is also fractured and well-karstified, though to a lesser extent than the Bekhme aquifer (noticeable especially in outcrops).

\section{KARSTIFICATION AND KARST FEATURES}

During the long geological history, especially in the Mesozoic and Tertiary periods, a lot of soluble rocks like limestone, dolomite and evaporites were deposited. This enabled the development of strong karstification and the formation of surface as well as underground karstic morphology. It can be concluded that the main cycle of karstification took place during Paleocene period. The second cycle of karstic process development occurred 
during and after the Oligocene-Miocene period and is still active.

Alpine folding and uplifting of mountains built of carbonate rocks caused stronger penetration of surface water underground. This was reinforced by numerous fissures, joints and fault surfaces, and the deepening of the basis of karstification. The uplifting of carbonate massifs and their intensive folding and faulting, repeated in several phases.

The initial phase was related to the land surface when the palaeo-drainage network was formed. In the central part of the area numerous deep canyons were formed (Fig. 4).

The karstification was also stimulated by specific climatic conditions, especially with the exchange of periods of high humidity and dry seasons (Stevanovic \& Iurkiewicz 2004b).

The holokarst of Iraqi Kurdistan is relatively specific. Compared with other karstic Euro-Asian mountainous ranges, formed during the Alpine orogenic cycle (Alpides, Dinarides, Hellenides, Taurides) typical larger surface forms such as sinkholes or dolines are not as frequent in this region. Some large depressions resemble the polje forms, but they are always open into the direction of the main drainage stream. Even if they are formed by karstic process, they have been strongly modified by surface fluvial process.

Deep groundwater circulation was formed in some cases with very large underground channels. An example was identified during the implementation of the FAO Programme in drilling (August, 2000) when a cavity of $30 \mathrm{~m}$ was drilled in Bekhme after reaching a depth of 80 $\mathrm{m}$ in Goratoo village (Erbil governorate).

The upper limit of younger Pila Spi aquifer is represented mainly by two important aquitard formations i.e. Lower Fars (Fatha Fn.) and Upper Fars (Injana Fn.)

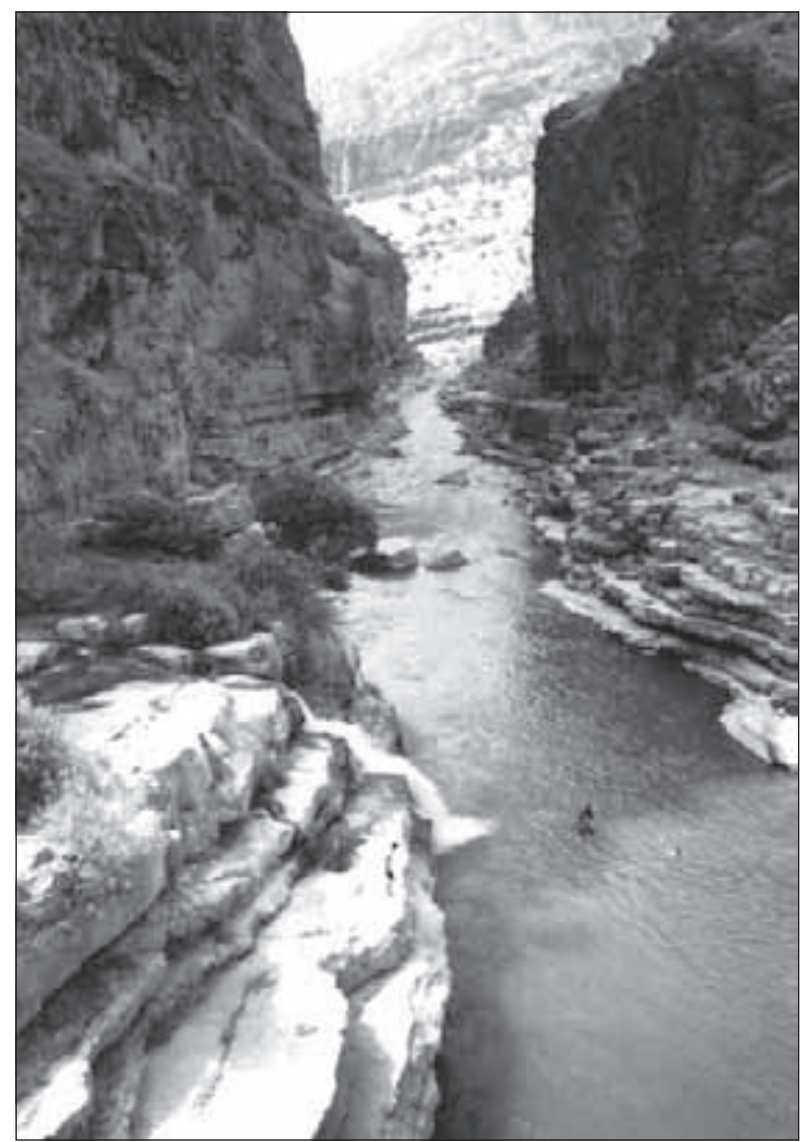

Fig. 4: Rawanduz Gorge, confluence of Khalifan (Alana) river. (Photo: Z Stevanović)

that frequently induce specific water chemistry. From the base to the top, the Lower Fars Fns. is an alternation of conglomerate, gypsum and anhydrite, salt rock, green marls, limestones, sandstones and red claystones. Bituminous and sulphur components are also present.

\section{EXPLORED CAVES}

\section{SHANIDAR CAVE (SHKAFT MAZIN SHANIDAR - SHANADAR BIG CAVE) (No. 1 ON FIG. 3)}

Location: Erbil Governorate, Barzan area, Shkaft village, c. 550-600 m a.s.l.

According to local (oral) history, the name Shanidar probably came from Shah Nadir, a prince who settled around Shanidar village about 200 years ago. The southern part of the Shanidar valley was inhabited by Christians (c. 400-500 AD) and so the name should be "Shani-der" - a place where a Christian monastery had stood ("shani" means collector and "der" means church or monastery).

Shanidar cave was carved into the massive limestone of the Lower Cretaceous age (Qamchuga Fm.). The cave consists of one great entrance hall and one small chamber, without any further accessible channels (Fig. 5). The entrance and main hall of Shanidar cave are among the largest in the area $-15 \mathrm{~m} \times 25 \mathrm{~m}$, but the total explored length of the galleries is estimated to be less than $100 \mathrm{~m}$. It probably represents the fossil spring of a carbonate aquifer discharging at an earlier stage on the right bank 
of a hanging valley, predisposed by a regional fault. It is interesting to note that the cave still fulfills in silence its millenary fate: in order to provide shelter for large herds, several Kurdish shepherd-families exploit Shanidar cave during winter.

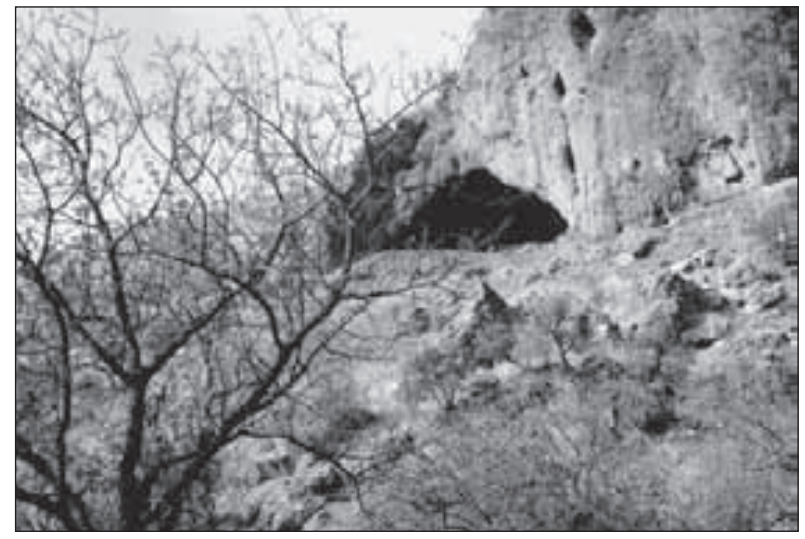

Fig. 5: Entrance of Shanidar Cave. (Photo: A. Maran).

Shanidar cave is well-known worldwide for Neanderthal skeletons (c. 60,000 years ago) found here. In the late 1950s, archeologist Ralph Solecki and his team unveiled four cultural layers within the cave: Layer A (recent to Neolithic); Layer B (Mesolithic); Layer C (Upper Paleolithic) and Layer D (Middle Paleolithic). During the years of investigation, thirty-five bodies were excavated with different artifacts. However, the first and the most famous exhumation belongs to an elderly male known as Nandy (Figs. 6, 7).

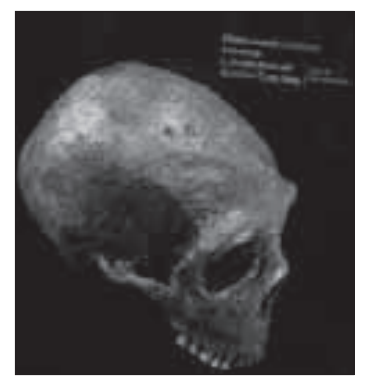

Fig. 6: Replica of Neanderthal skull (American Museum of Natural History, New York). (Photo: A. Maran).

The discovery of pollen grains around the adult male skeleton from Shanidar IV was also exclusive to Shanidar: it provides the best evidence of Neanderthal funeral rituals (Solecki Ra. 1975). Pollen analyses taken from soil samples around the burial in Shanidar IV revealed more than 20 different plant species that may have been chosen for their medicinal purposes: Bachelor's Button, St. Barnaby's Thistle, Grape Hyacinth, Cornflower, Hollyhock and others, all of which have long-known curative powers as diuretics, stimulants, and anti-inflammatory properties.

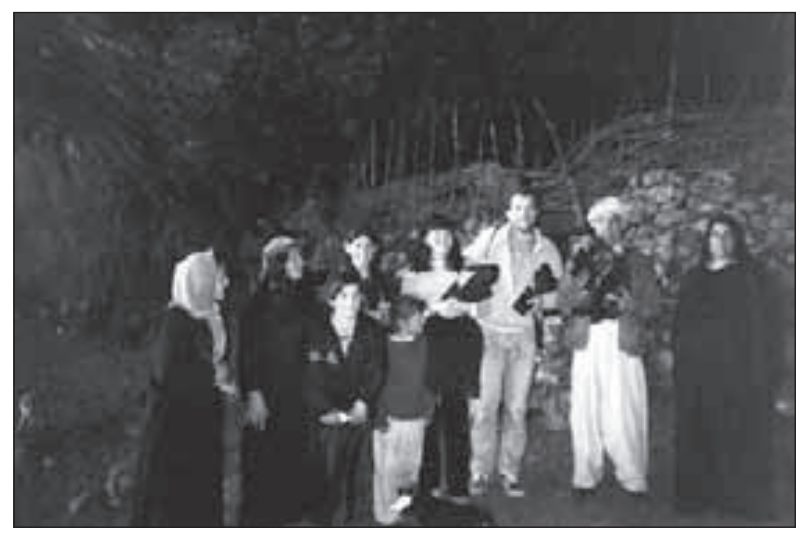

Fig 7: Visitors and inhabitants of Shanidar cave, winter 2002 (Photo: A. Maran).

These finds initially indicated that the skeleton from the Shanidar IV burial probably represented a medicine man with shamanic powers. Subsequent research suggested that the pollen perhaps was introduced by animal action as several burrows of a gerbil-like rodent (Persian jird) were found nearby. The jird is known to store large numbers of seeds and flowers in its burrows. This aspect, supported by the evidence that other skeletons did not contain any ritual treatment, suggest a natural, and not a cultural, origin of the Shanidar IV burial.

\section{BASTON CAVE (2)}

Location: Erbil Governorate, Bradost Mt., between Rawanduz valley (near Bekhme) and Dyana basin

It is one of very few caves that is well-known in the region and visited relatively often by local scientists and tourists as well. It was formed in the Bekhme massive limestone of the Sennonian age. The total length of all accessible channels is around $450 \mathrm{~m}$ (Fig. 8). The speleothemes and the size of the cave put it among the most attractive sites in the region (Fig. 9).

The entrance of Baston cave is located at the highest altitude e.g. 1,200 ma.s.l. among the currently explored caves. Due to its position, much higher if compared with the actual erosional base level represented by Rawanduz river, the cave is almost completely dry, thus only percolation water could be seen after heavy rains. Several parallel intra-bedded cave openings (1.5 $\mathrm{m}$ height $\mathrm{x} 8 \mathrm{~m}$ wide) connect to one large and well developed main channel which gradually deepens towards the following sectors of the cave and the pothole at its end.

The position and orientation of that channel indicate that infiltrated water was the main factor originat- 


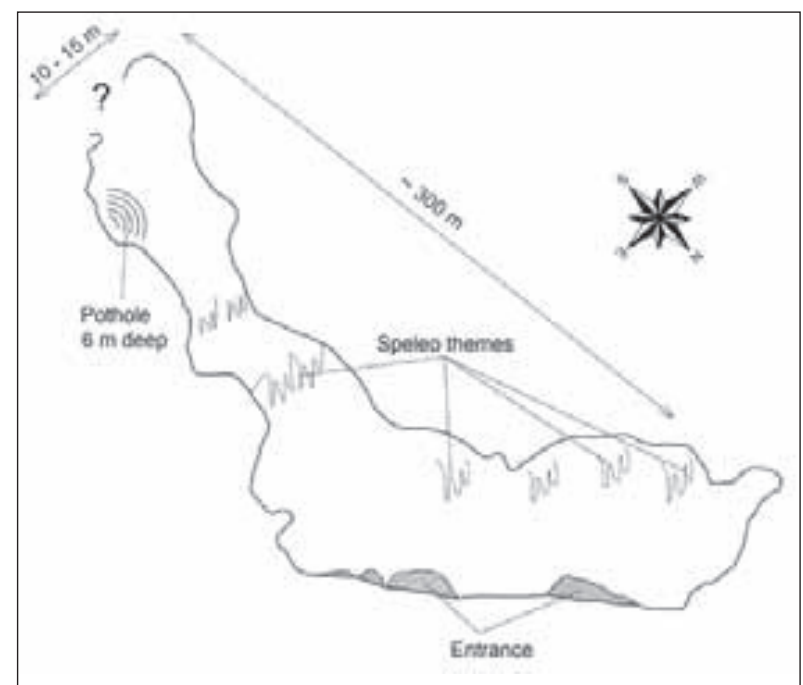

Fig. 8: Plan of the Baston cave.

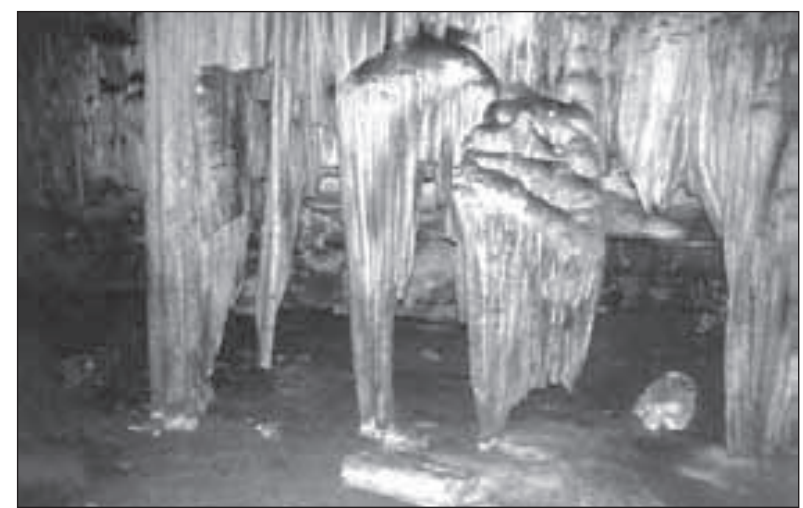

Fig. 9: Speleo-themes from Baston cave. (Photo: Z Stevanović).

ing the cave. Therefore, the cave is a fossil swallow hole developed by a sinking stream during the Late Neogene and Pleistocene times, located on the right bank of an actual hanging valley. By cutting and opening the water pathway, the tectonics also had a significant role in the cave inception.

\section{BETKA CAVE (3)}

Location: Sulaimani Governorate, Makok Mt., Saruchawa spring and village (near Chwar Qurna and Rania)

Saruchawa (in Kurdish "the eye of the spring") - the village, valley and spring of the same name are located some $50 \mathrm{~km}$ from Sulaimani at the foothill of Makok Mt. and at the western bank (side flank) of Dokan Lake. This group of springs belongs to the largest spring in the region, yielding a minimum of some 700 l/s (Fig.10). It was first described in Parsons Co. report (1955) as the "principal source of supply in Saruchawa Valley of both domestic and irrigation needs".

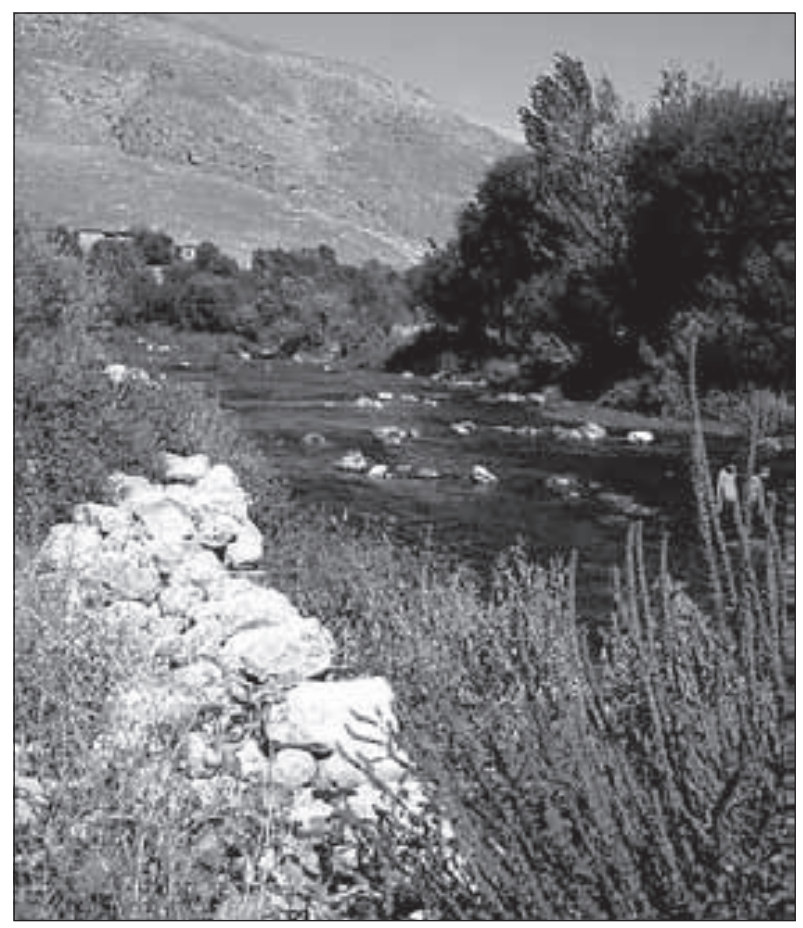

Fig. 10: Saruchawa spring at Makok Mt. foothill. (Photo: A. Iurkiewitz).

Betka Cave is the largest speleological objective in the entire Saruchawa catchment. From Kala Saida Saroo village (50-60 m relative altitude, right bank of the Shaori Valley) the boundary between the layers of Sarmord Fn. and the overlying karstified limestone of Qamchuga Fn. can be easily followed for some $500 \mathrm{~m}$ contouring the mountain slope parallel with the valley.

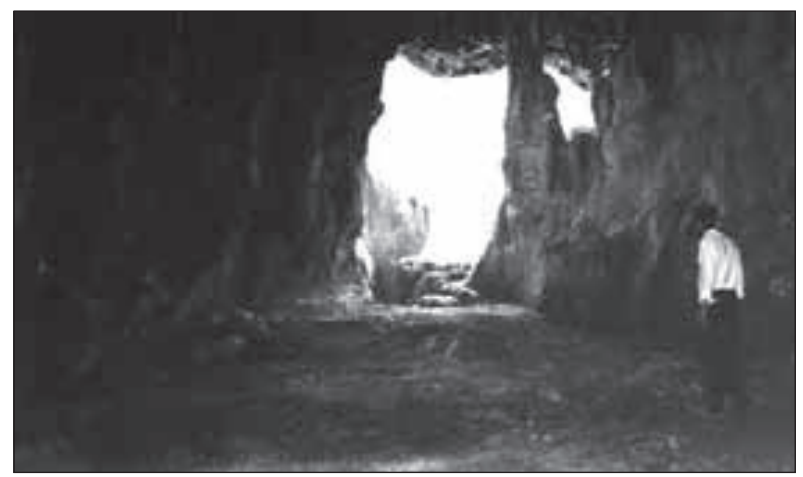

Fig. 11: The rectangular entrance in Betka Cave. (Photo: A. Iurkiewitz).

After reaching a right tributary (confluence in Nora Village), one can see the entrance to the Betka Cave carved in Qamchuga Fn (Fig. 11).

At the entrance there is a hall, $20 \mathrm{~m}$ in length, 6$7 \mathrm{~m}$ in width and $8-10 \mathrm{~m}$ in height, ending in a pile of collapsed blokes. From the entrance the main channel 
changes to a SE direction and the pathway seems to disappear $100 \mathrm{~m}$ from the entrance.

What is the relationship between the cave and Saruchawa? Is this the way to the underground Saruchawa River? The pieces of information collected from some apparently reliable sources are compatible and show no evident exaggeration. According to these data the noise of a big river and even the river itself can be reached after 2-3 hours of climbing down through galleries and very narrow passages. Stories from peshmarga groups finding a shelter during the harsh repression period in 1970s and 1980s also testify to the underground river.

\section{ZALUM (OR ZALM OR ZULUM) (4)}

Location: Sulaimani Governorate, Iranian border, Zalum spring and Khurmal village, $816 \mathrm{~m}$ a.s.l.

It is one of the strongest and most impressive springs draining the "Bekhme" aquifer with a minimal discharge of around 400 1/s (Fig. 12). The name of the valley and spring is possibly related to the word $z$ halm which means injustice. According to legend, some three hundred years ago an innocent was taken by mistake into custody and imprisoned in this valley. The traces of the small prison are still visible on the right side of the valley.

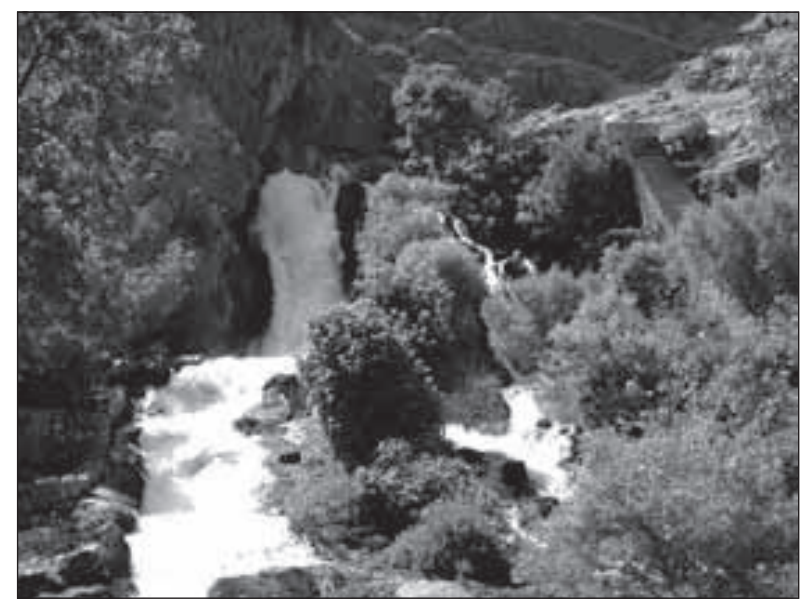

Fig. 12: Zalum spring waterfall. (Photo: A. Iurkiewitz).

Access to the area is by the road from Said Sadiq and Khurmal through Ahmad Awa. The majority of catchment is within Iran (the border is just a few kilometers further). The horizontal massive (or thick bedded 2-2.5 m) layers of Avraman limestones outcrop around the spring. The scenic waterfall of the spring (25 $\mathrm{m}$ high) is already a symbol among the major karst phenomenon in northern Iraq.

At the top and main discharge point it can be seen that water flows from the cave, easily accessible dur- ing the low water season. The cave is a unique gallery of $15 \mathrm{~m}$ descending slightly to the subterranean watercourse. According to the local technician that maintains the hydropower station, during the height of the drought period (when the spring discharge reached $400 \mathrm{l} / \mathrm{s}$ only) locals entered the water narrow passage and continued the exploration of the cave through a gallery with lakes estimated to almost $1 \mathrm{~km}$ (Fig. 13).

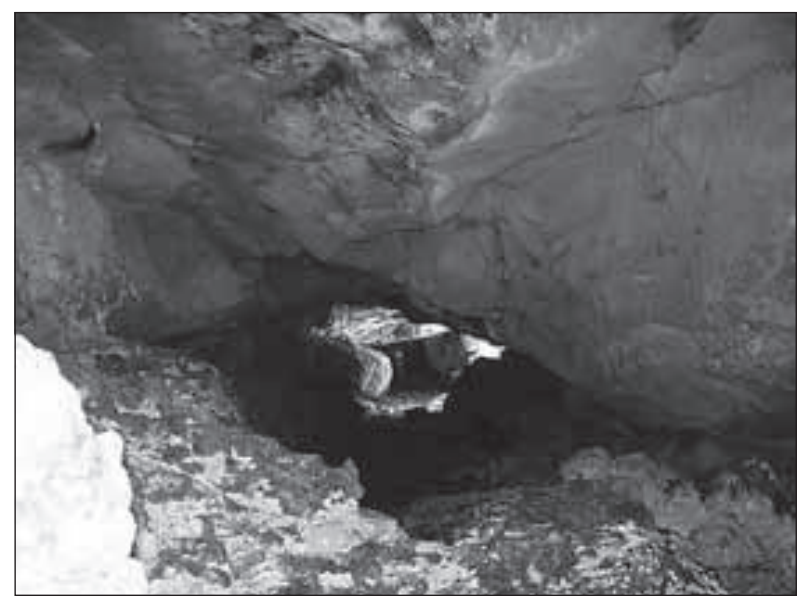

Fig. 13: Zulum overflow gallery. (Photo: A. Iurkiewitz).

\section{KUNA MASI (FISH CAVE) (5)}

Location: Sulaimani Governorate, Small Zab catchment, Chwarta area

The geologic framework of the area consists of the plunge of a small anticline with Kometan limestone to the core overlaid by Shiranish marls dissected by a transversal fault that likely controlled the location of the two outlets from the system. Two holes are located at this lithologic contact close to the hinge of the anticline (Fig. 14). The lower one is a large abris (shelter) and first exit point of the water from the system. The upper one is the penetrable entrance to the system, explored for about ten metres to a small pit (4-5 m) from where a lake that discharges laterally out of the cave and an upstream gallery are visible. Although the explored part is very small, the potential of the cave seems very significant, as suggested also by the high variability of the spring from about $10 \mathrm{l} / \mathrm{s}$ to over $500 \mathrm{l} / \mathrm{s}$.

\section{KUNA BA CAVE (6)}

Location: Sulaimani Governorate, Darbandikhan village, Golan Mt., Bani Khelan spring catchment

Kuna $\mathrm{Ba}$ (or Kuna Baa) is the largest speleo system developed within Pila Spi limestones. The catchment area covers the outcropping Pila Spi crust that forms both limbs of the Golan anticline (Fig. 15), a narrow structure 


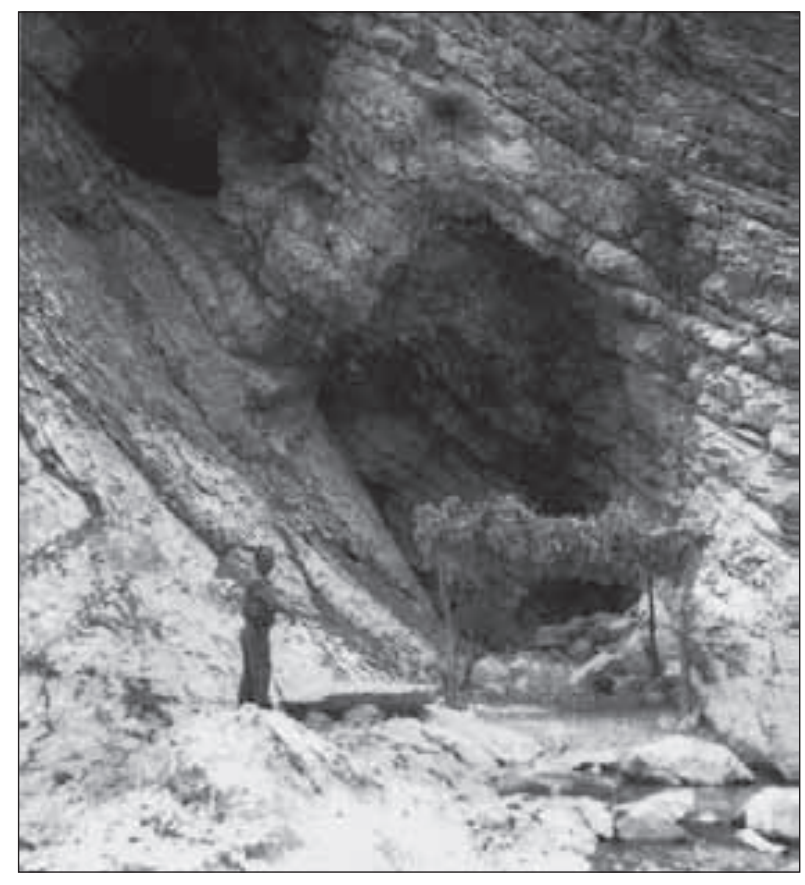

Fig. 14: Kuna Masi caves. (Photo: A. Iurkiewitz).

of about $1 \mathrm{~km}$ in width and $10 \mathrm{~km}$ in length crossing the Sirwan River almost at its southwestern plunge where the karst system is drained.

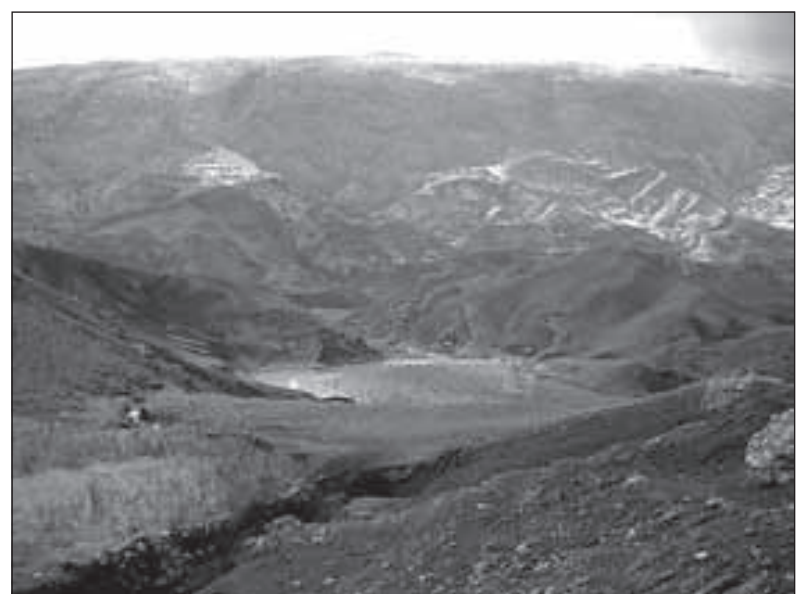

Fig. 15: Golan Mt. (Photo: Z Stevanović).

A reverse strike slip fault even developed to a thrust fault can be recognized in the axial plain of this structure. The Kuna Ba cave (700 m a.s.l.) explored to a length of about $500 \mathrm{~m}$ is probably related to the major trend of that fault (Figs. 16, 17, 18). The small entrance tunnel leads to large quasi-horizontal halls decorated with a variety of speleothemes (stalagmites, stalactites, stoneflows etc.). Lateral pits convey the percolation water to the deeper levels of the cave. There is no clear information about the accessibility of the passages to a possible main drainage

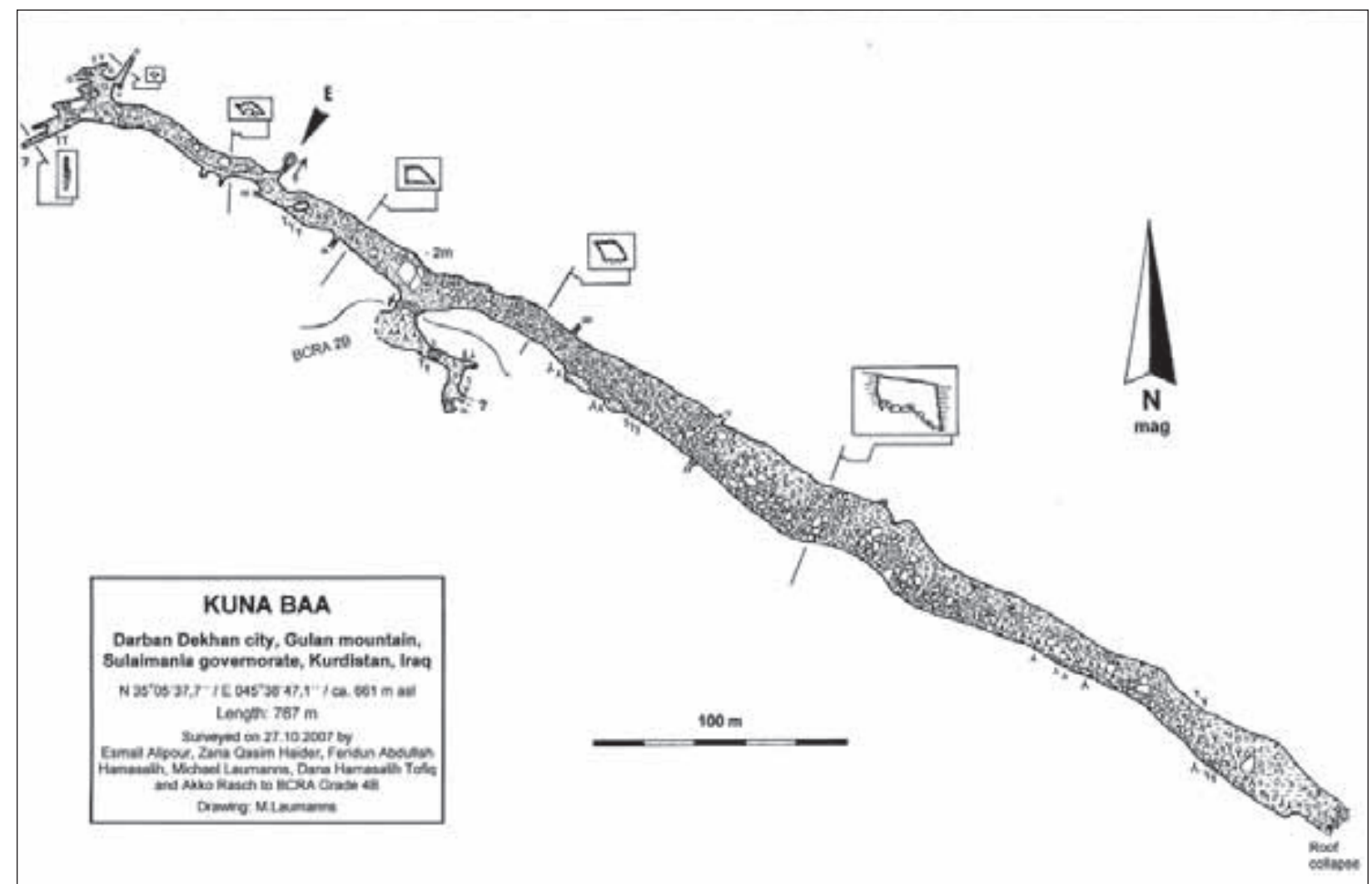

Fig. 16: Plan of Kuna Ba cave (after Laummans et al. 2008). 


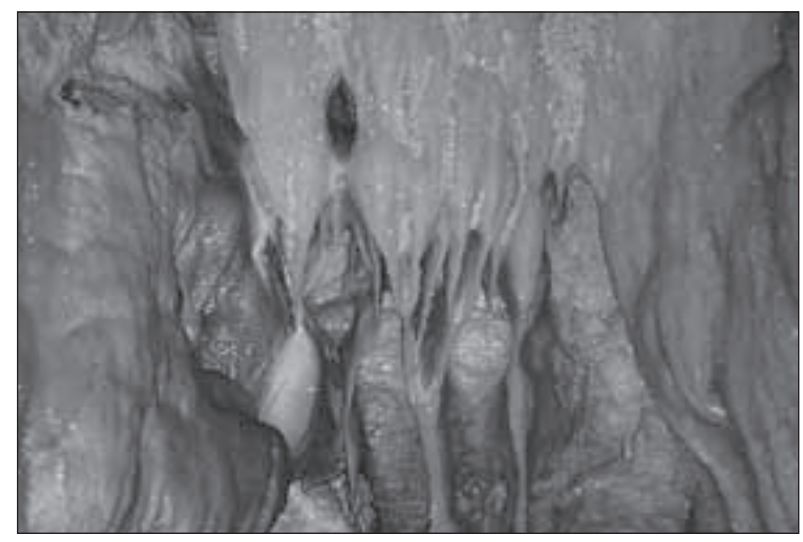

Fig. 17: Kuna Ba speleothemes. (Photo: A. Iurkiewitz).

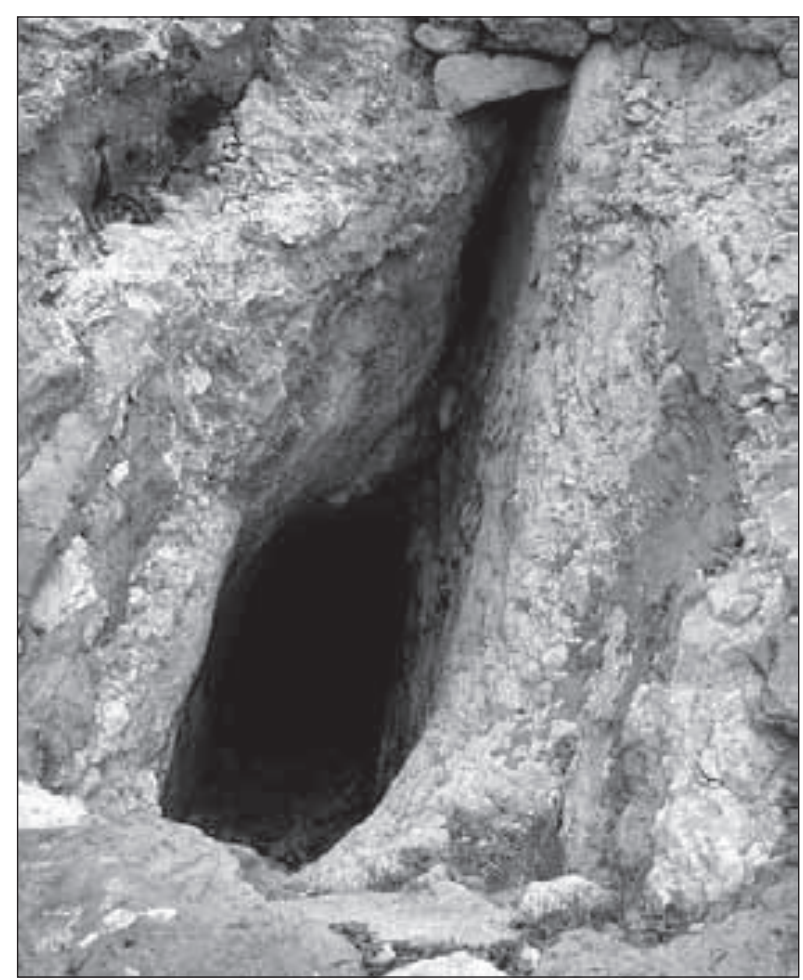

Fig. 18: Kuna Ba main entrance. (Photo: A. Iurkiewitz).

collecting the infiltrated water or about the structure of the end part of the system. However, the recent German - Kurdish exploration of that cave extended total length of explored channels to $767 \mathrm{~m}$ (Laummans et al. 2008).

The outlet of the karst system is most probably represented by a group of springs (fresh and sulphide water) located in close vicinity to the Bani Khilan village, $78 \mathrm{~km}$ from Sulaimani City following the road through Darbandikhan to Kalar. Hypothetically, the cave system was developed by a sinking stream that drained the former lake of Darbandikhan depression during the Pleistocene era. Apart from the regional faults, several local (transversal) faults had predisposed the main groundwater pathway and oriented the cave development towards Sirwan valley as the main erosional base.

\section{BETAS CAVE (7)}

Location: Dohuk Governorate, Betas village near Zakho, the upper catchment of Khabour River, Chiai Spizah Mt. at around $880 \mathrm{~m}$ a.s.l.

The cave is relatively small, carved also in Pila Spi limestones. From the main entrance $(1.5 \mathrm{~m}$ height $\mathrm{x} 8 \mathrm{~m}$ length) there is one large and steep sub-vertical gallery descending towards the bottom lake (groundwater table). The vertical difference is about $35 \mathrm{~m}$, while the total gallery length is around $120 \mathrm{~m}$.

The position and orientation of the cave indicate that this Pleistocene pothole-cave was probably developed by the sinking stream, which also opened a small gorge upstream of the cave. The Betas cave is very poor in speleothemes probably because of its fast development and water table deepening. But it is very rich in bats. A large colony exists in the lower part of the cave.

The local villagers also benefit from this cave. The bottom lake - groundwater eye is exploited through a pump and pipe system and the water is used for irrigation during the hot summer months (Figs. 19, 20).

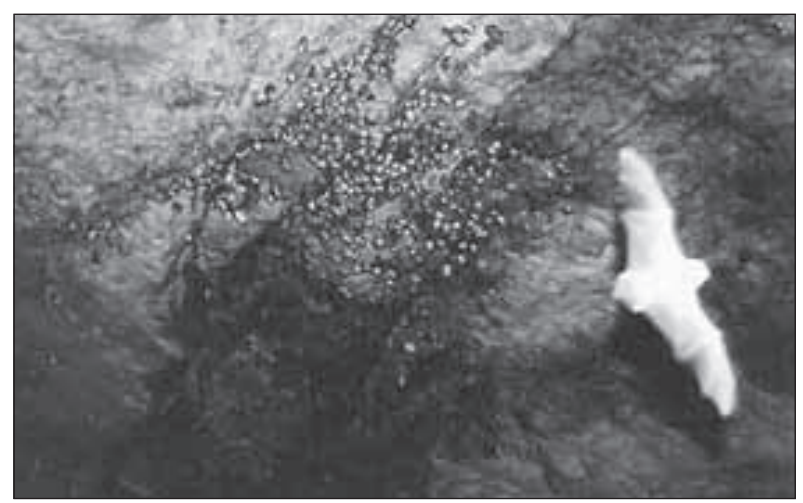

Fig. 19: Betas bats. (Photo: Z Stevanović).

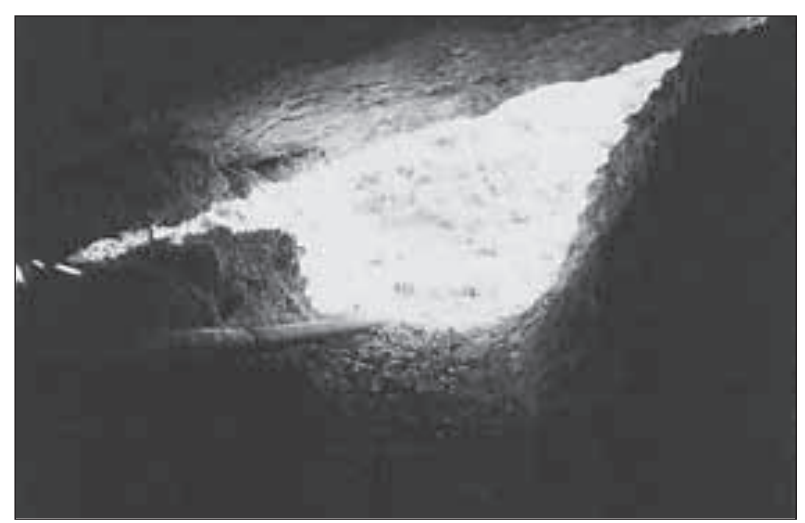

Fig. 20: Betas entrance and water pipes. (Photo: Z Stevanović). 


\section{CAVES IN EVAPORITIC AND SULFIDE KARST}

The presence of sulfide springs in the northeastern part of Iraq is ordinary rather than exceptional. A fairly important number of springs with $\mathrm{H}_{2} \mathrm{~S}$ degasing were identified in all three structural zones of the studied area, but the major occurrences are within the Low Folded Zone in the south, where evaporite layers prevail.

The frequent incidence of sulfide water flow could be considered a logical consequence of the existence of rich oil fields inferred on the base of lithology and structural framework. Bituminous matter in carbonate layers occurring in Northern Iraq were described as (shale) horizons or dispersed within formations of different ages from the Jurassic to the Upper Cretaceous as well as the Tertiary. The presence of sulfate component is often prerequisite for $\mathrm{H}_{2} \mathrm{~S}$ generation and its further influence on karstification intensity and creation of specific features. Thus, the reduction of sulfate to sulfide occurs in nature under anaerobic conditions in the presence of sulfate-reducing bacteria and a source of organic carbon. Hydrogen sulfide-rich waters rise up into carbonate strata and become oxidized, thus producing sulfuric acid. The oxidizing process may occur either through abiotic or microbial oxidation reactions (Summers 2000; Klimchouk 2005).

\section{SMAQULI KROZH CAVE (8)}

Location: Erbil Governorate, $2 \mathrm{~km}$ from the main road to Rania, after the branch to Koya, Smaquli Gali valley, Bnabawagi and Awa Kurds Mts.

The Smaquli Krozh cave, located in the upper part of the valley (approx. $600 \mathrm{~m}$ a.s.l.), is carved within Shiranish well-bedded marly limestones. Shiranish Fn. although carbonated enough in its lithological definition, is mostly aquitard and only the lower part at the contact with Qamchuga limestones (as in this case) is somehow karstifiable and accordingly could represent an aquifer. The whole area is closely fissured and accordingly moderately weathered and karstified. Apart from the gorge shape of the valley and the presence of the springs a collapse doline on top of the hill (that most likely corresponds to the fracture and material fall in the last hall) can be included among the few exokarst features of the area.

This is one of the major caves genetically based on the $\mathrm{H}_{2} \mathrm{~S}$ and sulphuric acid karstification factors (Figs. 21, 22). The outlet locations are probably linked to a large fault that also facilitated the development of the Smaquli Gali gorges (Hizop Valley). Sarwchaway Krozh is an important group of sulphide and fresh springs, representing almost half of the water flowing down through Hizop valley. At the exit from Hizop Gorge, two other sulfide springs represent a local tourist attraction.

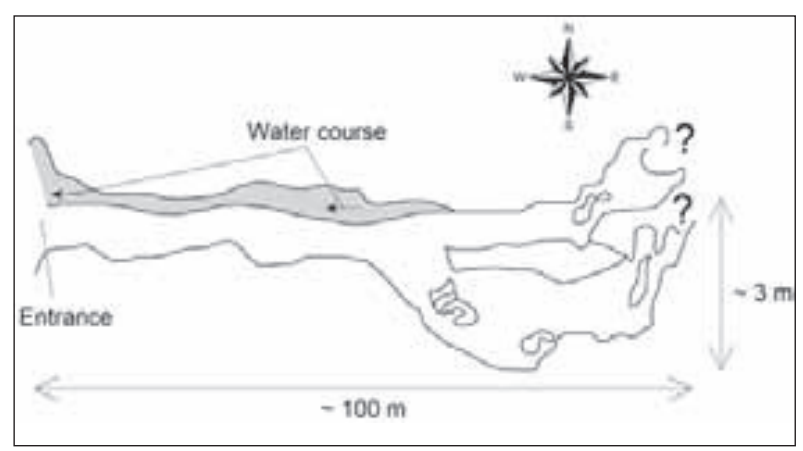

Fig. 21: The sketch map of Smaquli Krozh.

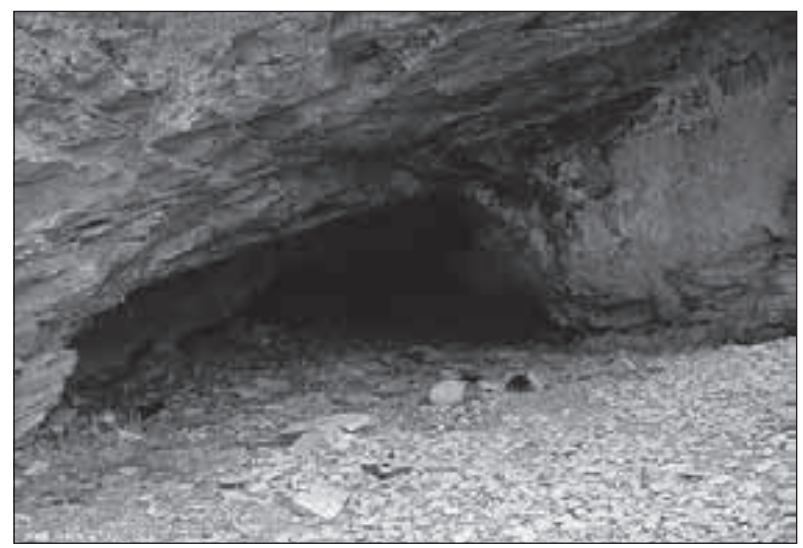

Fig. 22: The main cave entrance of Smaquli Krozh. (Photo: A. Iurkiewitz).

After $40 \mathrm{~m}$, a first junction separates an upper level from the slightly sloping down gallery which leads to the active level of the cave. The active stream originating in the cave is intercepted after $35 \mathrm{~m}$. The slightly acidic water stream, spreading a rotten egg odor, can be followed upward and downward for only 7-8 m. The easily accessible section of the gallery ends after $20 \mathrm{~m}$ in a maze system of narrow and small galleries.

The upper level is almost a long and high hall hosting a rich colony of bats. It ends in a rounded loop imposed by the fracture system. In fact, the whole genesis of the cave is clearly related to the tectonic features (important longitudinal - transversal systems of fractures). The presence of the clay (mud) on the cave bed and walls is witness to the frequent floods. The highest level (third) of the cave is partially developed only at the end part of the cave, above the previously described loop gallery. All galleries change their shape close to the end part and become more and more impassable. The total area of galleries is close to $250 \mathrm{~m}$, while the maximum difference between the active stream and the highest point is not more than $20 \mathrm{~m}$. 
The main fracture system in the area is $240 / 80$ but inside the second cave a longitudinal vertical fracture visible for at least $5 \mathrm{~m}$ (height) seems to initiate and control the karstification process. A small but deep fresh water lake represents the actual end of the $20 \mathrm{~m}$ long gallery where the voids become tight and narrow.

Different hypotheses relying on geological and chemical arguments can be combined to offer an explanation of the presence of some freshwater springs but also of some of the sulfide type in the same drainage zone. However, the role of a deep regional fault seems to be crucial in conveying the ascending flow of the late mentioned. The streamflow inside the cave could be a mixture of both fresh and sulfide water.

\section{AWA SPI (9)}

Location: Sulaimani Governorate, Garmian area, Sagrma Mt., Sangaw, Darzila village (south of Hazar Kani village)

The road going from Sangaw to Darzila is mostly parallel with the axis of a large syncline located between Sagrma Mt. and the chain of small anticlines that ends towards the SE with the double plunging Azdagh anticline. A transversal valley offers a spectacular cross section through Lower Fars evaporite layers until it reaches the Pila Spi limestone (Fig. 23).

From that point, the gentle slopes of the valley change to steep, almost vertical, banks and after some $200 \mathrm{~m}$ the valley is replaced by an impressive canyon that can be followed for almost two kilometers. The river cut the Pila Spi limestone deeper and deeper and in its middle sector the canyon is close to 50-60 m deep and 5$10 \mathrm{~m}$ wide. The high degree of karstification is witnessed by karrens of different sizes ( $\mathrm{cm}$ to metric) and enlarged fissures, small caves and rock shelters, taffoni, spectacular escarpments and circular pools in the river bed, all contributing to the surprising panorama of this canyon in the middle of one of the warmest regions of the Iraqi Kurdistan, the so-called Garmian (garm=hot) area.

The local tectonics, including a set of 4-5 visible fractures (faults), contribute to the increased degree of weathering and karstification of this sector. Some $150 \mathrm{~m}$ downstream a narrow but deep crack is one of the openings of the system.

Strong $\mathrm{H}_{2} \mathrm{~S}$ exhales (rotten egg odor) and the noise of a possible important streamflow suggest the presence of an underground river in the Awa Spi system. At short distances, a chain of 3-4 sinkholes track on the surface the main course of the water. Inside, some of these openings are immediately connected through low and narrow galleries but the road to the system is always vertical, imposed by a set of deep (25-30 m), narrow (0.5-1.5 m) open fractures.

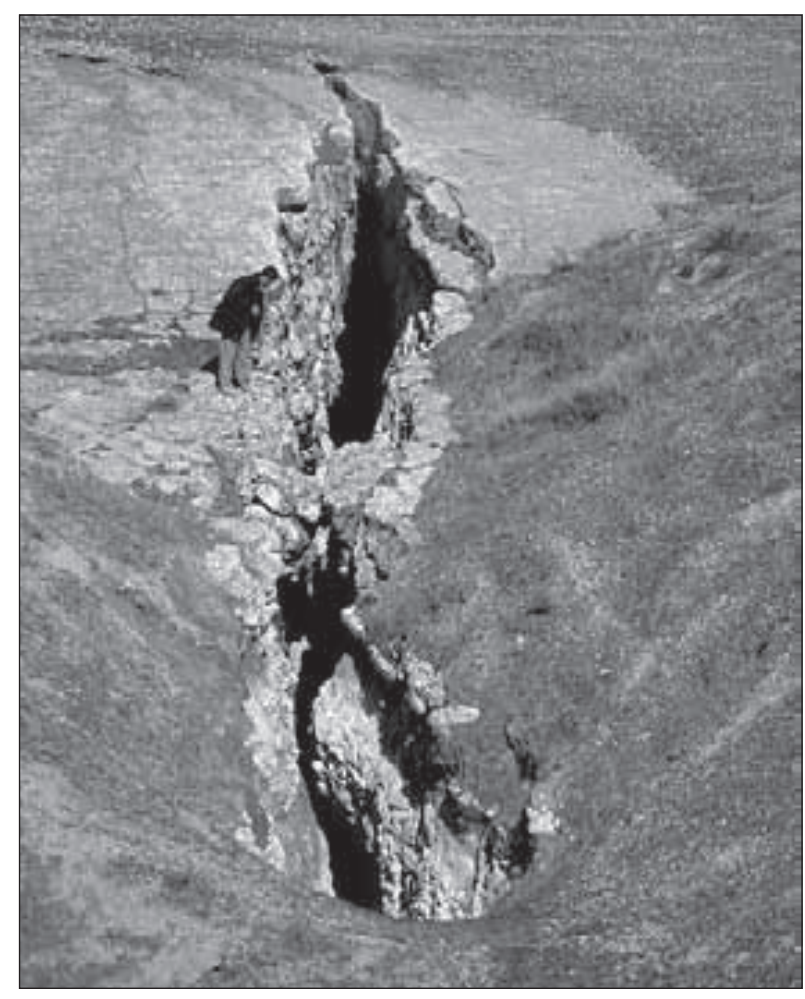

Fig. 23: Crevasse and sinkholes: Faulting area on the road to Awa Spi . (Photo: A. Iurkiewitz).

Together with the group of geologists from Sulaimani University that guided us during many common field trips we entered one of these crevasses and climbed down some 40-50 m inside the sinkhole. After passing a few cascades we reached a lower level represented by a secondary gallery with a small course of dark colored acidic water. Black bitumen and clusters of sulfur crystals but no stalagmite and stalactites decorate the gallery.

According to resident villagers, within the same area there is another cave about $2 \mathrm{~km}$ long (however the length is likely exaggerated).

During winter the stream is active along the whole canyon sector, but during summer the reduced streamflow of 5-8 1/s apparently disappears through the fissures (the lower level of the canyon is hardly accessible for proper survey).

At the end of the canyon, on its left bank, the main outlets of the system are represented by an active cave and positioned below a vauclusian type spring, Awa Spi ("white water", Fig. 24). Villagers investigated the cave to about $30 \mathrm{~m}$ but due to the high presence of hydrogen sulfide further exploration is dangerous. After less than 1 $\mathrm{km}$ the $\mathrm{H}_{2} \mathrm{~S}$ completely releases from the water and gypsum re-deposition occurs.

A hundred meters upstream on the right bank, two other acidic springs (white colored water of around 80-100 l/s during winter) discharge a secondary system 


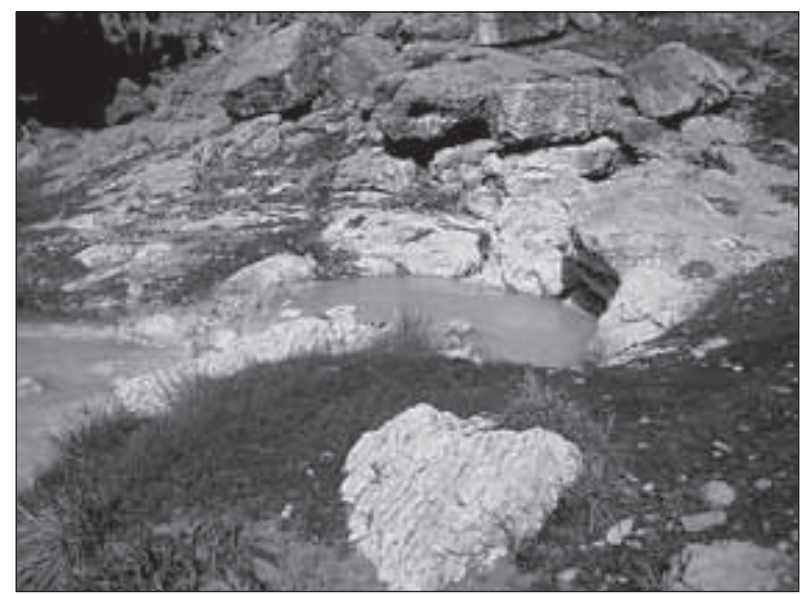

Fig. 24: Main spring of Awa Spi group. (Photo: A. Iurkiewitz).

joining the same geologic setting. The spring area is in fact the exit from the canyon. Some other fresh springs (4-5) were also investigated in the area, to a total of nine springs in all.

For chemical/dissolution processes and creating the Awa Spi system, two main factors are considered to be crucial:
1. Presence of gypsum (bottom layers of Lower Fars Formation) at the contact with Pila Spi limestone,

2. Possible affluxes of $\mathrm{H}_{2} \mathrm{~S}$ from deep and rich oil reservoir (the famous Kirkuk oil field is not that far from the place).

Gypsum dissolves rapidly in flowing water, at rates much higher than that of limestone. The solubility of gypsum in water is roughly 10-20 times greater than the solubility of calcite in the presence of $\mathrm{CO}_{2}$ (Klimchouk 1996). Whenever a groundwater flow system is established, caves in gypsum can enlarge at a rapid rate resulting in large chambers. Collapse of these chambers can propagate through the overlying rocks to break through at the surface and form subsidence hollows.

Several other caves and caverns were also identified and explored in evaporite rocks of the Garmian area, namely Mamlaha, Qayatool, Kweilin. They are, as in the case of Awa Spi, mostly the result of the dissolution of salty rocks and the presence of high concentration of $\mathrm{H}_{2} \mathrm{~S}$ and sulfide acid in the water. Some of the caves are a few hundred meters in length (villagers reported them to be passable for even more than $1 \mathrm{~km}$ ), practically following the main gypsum layers.

\section{CONCLUSION}

The karst of the northern part of Iraq (Southwestern Zagros Mts.) was mostly unknown to the scientists although about $35 \%$ of that region is covered by carbonate rocks with different degree of karstification. This karst has relatively different characteristics compared to other parts of the Alpine geosyncline system, a consequence of specific tectonic setting and climatic conditions. However, there are many large caves and karstic springs as a consequence of intensive groundwater circulation and well developed karstic aquifers after the end of Alpine uplifting and folding the mountains.

Most of the caves were carved within Bekhme and Qamchuga Cretaceous limestones and in younger Eocene Pila Spi Fn. Karstification of the Pila Spi limestone was not as intensive; however, development in privileged pathways, predisposed by the regional faults, resulted in numerous sub-surface forms, with lengths sometimes exceeding a hundred meters. In the southern part of the studied area several caves resulted from the dissolution of carbonate or evaporate rocks stimulated by water oversaturated in $\mathrm{H}_{2} \mathrm{~S}$ (gas migrated from deeper structures).

The conducted reconnaissance survey, despite the time limitations and the equipment used, has provoked in local researchers an interest in further work. However, the gate has opened and it was expected that the specialists from abroad will also be attracted to investigate this beautiful karst. The first such an opportunity was German - Kurdish speleological survey conducted by Laummans et al. (2008). The survey resulted with exploration of Kuna Kamtiar the longest cave of Iraq currently 5,060 $\mathrm{m}$ in length, and 20 other caves. Most of them are created by sulphuric acid water and belong to Low folded zone in the southern part of Sulaimani or Kirkuk governorates.

One such cave is Tirshawaka, in which the sulphuric acid has produced a rind of replacement gypsum that covers the cave's roof and walls. The source of the sulphur is supposed to be an underground hydrocarbon deposit (Laummans et al. 2008). Exploration of Tirshawaka was stopped in wide open river passage after $190 \mathrm{~m}$ of channels are mapped, but the resurgence of the cave river is supposed to be about $1 \mathrm{~km}$ further towards the northeast. Sahra Cave, situated in the valley of the Chamyrezan Zham River northwest of Sulaimani, was a stronghold of the Kurdish resistance during the Saddam regime. A small meandering passage provides access to an impressively large tunnel-shaped fossil collector with a diameter of $20 \mathrm{~m}$. It has a surveyed length of $1,088 \mathrm{~m}$ (Laummans et al. 2008). 


\section{ACKNOWLEDGMENTS}

Our warmest thanks go to our colleagues from Food and Agriculture Organization of United Nations and local universities of Erbil and Sulaimani with whom we have closely worked during our stay in Iraq. We are gratefully acknowledged the field work and the assistance to exploring the caves provided by Fadel Lawa Ameen, Salahalddin Saeed Ali, Kamal Haji, Dler Baban from Sulaimani University.

\section{REFERENCES}

Braidwood, J. R. \& B. Howe, 1960: Prehistoric investigation in Iraqi Kurdistan.- Oriental Institute of University of Chicago, Studies in ancient oriental civilization, 31, p. 184, University of Chicago press, Chicago-Illinois

Braidwood R., Braidwood L., Howe B., Reed A. \& P. Watson, 1983: Prehistoric Archeology along the Zagros Flanks, Oriental Institute Publication, 105, p. 695, Chicago.

Buday, T., 1980: The regional geology of Iraq. Vol. 1. Strartigraphy and paleogeography.- SOM, Baghdad

Buday, T. \& S. Z. Jassim, 1987: The regional geology of Iraq. Vol.2. Tectonism, magmatism and metamorphism.- Printing Dept., S.E. Geol. Surv. and Mineral Invest., p. 352, Baghdad.

Dubertret, L., 1959: Lexique stratigraphique international. Asie. Fascicule 10a, Iraq.- Center National Recherche Scientifique, Paris.

Klimchouk, A. B., 1996: Gypsum karst of the world. Speleogenesis in gypsum, International Journal of Speleology, 25, 3-4.

Klimchouk, A.B., 2005: The role of karst in the genesis of sulphur deposits, Pre-Carpathian region, Ukraine / Speleogenesis and Evolution of Karst Aquifers 3, 2, www.speleogenesis.info, p. 23. re-published from Environmental Geology 1997, 31, 1/2, 1-20.

Laumanns, M., Rasch, A. \& Ph. Audra, 2008: Karst and Caves of Iraq (including the results of a 2007 Kurdish-German speleological project and an overview on hypogenic sulphidic speleogenesis).- Berliner Höhlenkundliche Berichte, 26, Berlin.

Maran, A., Cherwani, G., Lawa, F., Stevanovic Z. \& A. Tahir, 2004: Towards recognition of Iraqi Kurdstan geo heritage, Books of Abstracts of $32^{\text {rd }}$ International geological congress.- Part 1, Sci s. 137-9, p. 605, Firenza.
Numan, N.M.S., 2002: Tectonic investigations in northern Iraq.- Report, FAO North Documentation Fund. Erbil (unpublished).

Parsons Company, Ralph, M., 1955: Ground-water resources of Iraq.- Volumes 1-9, Los Angeles - Baghdad. Development board, Government of Iraq, Baghdad.

Solecki, Ralph, 1952: A Paleolithic Site in the Zagros Mountains of Northern Iraq.- Report on a Sounding at Shanidar Cave, 1, 8, 127-161.

Solecki, Ralph, 1998: Archaeological survey of caves in Northern Iraq.- International Journal of Kurdish Studies, 12, 1 \& 2:1-70.

Solecki, Rose, 1981: An Early Village Site at Zawi Chemi Shanidar.- Bibliotheca Mesopotamica, 13: Undena Publications, Malibu

Stevanovic, Z. \& M. Markovic, 2004: Hydrogeology of northern Iraq, Vol. 1. Climate, hydrology, geomorphology and geology.- Spec. Edition TCES, FAO / UN, Rome.

Stevanovic, Z. \& A. Iurkiewicz, 2004a: Hydrogeology of northern Iraq, Vol.2, Regional hydrogeology and aquifer systems.- Edition TCES, FAO / UN, Rome.

Stevanovic, Z. \& A. Iurkiewicz, 2004b: Karst of Iraqi Kurdistan - Distribution, development and aquifers.- Receuil de raports, vol. VIII, Spec.ed. Serb. Acad. of Sci., b. DCLVI, 2, 31-53, Belgrade.

Stevanovic Z. \& A. Iurkiewicz, 2004c: Geologic-tectonic factors controlling groundwater flow patterns and discharge of karst aquifers in Western Zagros (Northern Iraq), Proceedings of $33^{\text {rd }}$ IAH Congress $\& 7^{\text {th }}$ ALHSUD (CD) Zacatecas.

Summers, E. A., 2000: Microbially-enhanced weathering in subsurface habitats: sulfur-oxidizing bacteria and the cave environment.- Karst Studies and Problems: 2000 and Beyond. Proceedings of the joint meeting of Friends of Karst, Theoretical and Applied Karstology and IGCP 448, Cluj-Napoca. 